\title{
Counteractive Strategies in Colonial and Postcolonial Narratives of Memory Joseph Conrad's Heart of Darkness and Anita Desai's Clear Light of Day
}

This paper examines the role of memory in colonial and postcolonial literary narratives. In postcolonial and colonial literary discourse, memory spaces are fiercely contested. Joseph Conrad's Heart of Darkness (1906) and Anita Desai's Clear Light of Day (1980) are respectively colonial and postcolonial narratives in which indigenous and colonial subjects configure preserving their ways of remembrance. Colonial ways of remembrance collide with indigenous ways of remembrance. The colonial subject imposes its ways of remembrance on indigenous subject. Consequently, the indigenous subject counteracts the colonial ways of remembrance. 
We have heard the chimes at midnight.

William Shakespeare, Henry IV

We organize our experience and our memory of human happening mainly in the form of narrative.

Jerome Bruner

\section{INTRODUCTION}

Memory is a signifier of individual and collective identity. Personal and collective memory is entwined and interlinked. Michael G. Kenny $(1999,421)$ is of the view that "individual and collective experiences imply each other. All experience is individual in that collectivities do not have minds, or even memories, though we often speak as if they did. Yet it is also true that individuals are nothing without the prior existence of the collectivities that sustain them, that is, the cultural traditions and the communicative practices that position the self in relation to the social and natural worlds. Collectivities may not have minds, but an individual also does not transmit his experience without being part of one or other kind of collectivity." The individual and collective experience integrates into social and cultural collectivities. The transference of individual experience to collective experience, or the exchange between individual and collective experience, is a critical process. Scholars trace the genealogy of memory studies to Maurice Halbwachs's On Collective Memory (1992). Jeffrey K. Olick and Joyce Robbins $(1998,7)$ say that "though collective memory does seem to take on a life of its own, Halbwachs reminds that it is only individuals who remember, even if they do much of this remembering together." Collective memory, therefore, is not a hermeneutically stable category. It also means that individual memory works within a larger framework of collective memory. There is collation between individual and collective memory. My interest in examining the collation between individual and collective memory is primarily inspired by the collation between colonial and postcolonial literatures. Both colonial and postcolonial literatures are coproductive discourses. Colonial and 
postcolonial literary narratives employ memory as a narrative tool to fix and manipulate or destroy their respective ways of remembrance. There are points of intersections between colonial and indigenous ways of remembrance; Halbwachsian discourse envisages intersections between individual and collective memory. The relationship between individual and collective memory is both disjunctive and aligned. Thus, individual memory confronts with collective; colonial and postcolonial narratives mimic this confrontation. The locus of this confrontation is conflicting cultural contexts. Colonial agency relocates to territories and imposes its ways of remembrance on natives' minds and consciousness. Halbwachs $(1992,83)$ is of the view that "it is in society that people normally acquire their memories. It is also in society that they recall, recognize, and localize their memories." But in societies, in which one group feels alienated whereas another does not, the function of memory certainly becomes compromised. A particular dynamic of a particular society thus affects its ways of remembrance. Halbwachs envisages connection between individual and collective memory, but he is aware of the complexities of contextuality that an individual or group inevitably encounters. Colonial agency claims indigenous societies and their social contexts, and interferes with their ways of remembrance. Consequently, indigenous societies engage with colonial ways of remembrance, but they do not endorse it.

In other words, colonial and indigenous or postcolonial memories interact in different ways. In colonial and postcolonial literature, what lingers on memory actually adds up to the idea of one's sense of the individual, the group, and the nation. The colonial and postcolonial narratives concurrently explore interaction and confrontation between individual and collective ways of remembrance. Colonization, literally and metaphorically, created an atmosphere of collusion, engagement, and counteraction; indigenous individuals, groups, societies, or, for that matter, nations are forced to drop their lens of remembrance. They are conditioned to remember and recollect their indigenously rooted lives through colonial ways of remembrance. The colonizer enlists indigenous ways of remembrance for diagnosis and correction.

This paper argues that the indigenous subject counteracts the colonizer's ways of remembrance. I use two literary texts, Joseph Conrad's Heart of Darkness ([1906] 1992) and Anita Desai's Clear Light of Day ([1980] 2000). In both novels there is a confrontation between colonial and indigenous subjects; both strive to justify, establish, and preserve their respective ways of remembrance. Correspondingly, the 
main thrust of my argument is that colonial memories and indigenous memories interact and are made to interact in different ways. In both Heart of Darkness and Clear Light of Day, the authors employ complex narrative strategies, multiple voices and personae in order to show the confrontation between indigenous and colonial ways of remembrance. French historian Pierre Nora (2010, viii) calls it "instruments of memory." The instruments of memory have a generic base, however in different cultures these are utilized in different ways. The indigenous subject counteracts colonizer's way of recollecting local or native realities. The colonial machinery initiated an invidious project of uprooting natives' memory from their social and cultural moorings. Correspondingly, indigenous subjects enact counteractive strategies against colonial machinery.

I chose Heart of Darkness because this particular novel recollects the memory of ancient Africa from Eurocentric perspective, and Clear Light of Day because it recollects memory of the decolonized India from the postcolonial Indian perspective. In Heart of Darkness, the indigenous subject counteracts the colonial ways of remembrance from the subjectposition of individuals and scattered tribal groups, but in Clear Light of Day, the narrative creates a subject-position for the indigenous subject to counteract the colonial ways of remembrance from the nation's point of view. The section on Heart of Darkness examines the constructs of the African individual and group as problematic representations (recollections) of European memory of the African continent, whereas the section on Clear Light of Day examines the construct of the nation as a trope of the postcolonial ways of remembrance. The section on Clear Light of Day thus supplements and amplifies the postcolonial purview. Both texts on the narrative level antagonize colonial ways of remembrance. In Heart of Darkness, primitive tribal society is a template of African memory, while in Clear Light of Day, the nation is a template of memory. As colonial agency departs, the indigenous subject rediscovers the mental and psychological scars of colonization; indigenous memory besieged to colonial occupancy. Consequently, the postcolonial subject recuperates its ways of individual and collective remembrance from colonial structures of erasure.

I propose a theoretical framework that there are latent and connotative links between memory as it figures in a postcolonial sense, in a literary sense, and in a Halbwachsian sense. The basic premise is that the colonial subject interacts with indigenous sociological ethos; no single memory exists outside one or more kinds of contexts. Colonial 
and postcolonial literary narratives employ strategies to establish their methods of remembrance. In other words, literary memory refashions sociological memory to its ends. Each literary discourse, and text, is grounded on some or many sociological patterns. Each type of memory exercises a certain influence on other type of memory. Memories coexist, coalesce, and coproduce. Individual memory and collective memory are not separable and, by the same token, literary memory and postcolonial memory cohabit under a broader and flexible adjustment; literary texts inhabit disparate and amorphous memories of individuals and groups. The interaction between sociological and literary memory is productive. German literary critic Ansgar Nünning $(2008,106)$ is of the view that "literature can be virtually described as a privileged medium to represent individual memory [and] narrative texts in particular display forms that show a special affinity to memory." Literary memory and sociological memory are thus interfaced. In this way, memory captures a larger landscape of individual and collective remembrance, unfolding a compound grid of colonial memory, social memory, and literary memory. The discursive configurations of memories produce discursive contexts; therefore, each memory represents a material discourse operating in a group, society, and nation. By implication, memory enacts diverse recuperative strategies. Consequently, an individual's or a group's way of remembrance manifests its structures of power.

\section{INTERSECTIONS BETWEEN COLLECTIVE MEMORY AND (POST-) COLONIAL DISCOURSE: POWER DIALECTS}

Jan-Werner Müller $(2002,1)$ states that memory "matters for the simple reason that memory is an anthropological given [and] both individual and collective memory lies $[\mathrm{sic}]$ at the intersections of so many of our current concerns and organises many of our projects." The colonial project and the counterproject of postcolonialism are also organized by memory, because both compete and contest for establishing their ways of individual and collective remembrance. Both discourses write and rewrite each other's and one's own stories, which begin from the time of colonial entry to the moments of colonial departure, and extends indefinitely to a phase which is loosely interpreted as decolonization. Halbwachs $(1992,51)$ asserts that "the 
collective memory [...] encompasses individual memories while remaining distinct from them. It evolves according to its own laws, and any individual remembrance." The correlation between collective memory and individual memory suggests that Halbwachs envisages memory as a discourse of power; memory is monolithic in its collective capacity and divergent in individual capacity. Olick and Robins (1998, 18) elucidates Halbwachsian conviction that memory is concurrently a homogenous and heterogeneous entity: "memory is a matter of how minds work together in society, how their operations are not simply mediated but are structured by social arrangements." It means that where individual memory apparently exists without any specific context by obtaining contextuality, it evinces power under certain social arrangements. The attempt to show interrelatedness between an individual's mind and society is to suggest the ways an individual and a society manifest their drive for power. The colonial subject introduces its laws of remembrance to the indigenous subject, and disrupts the ways of remembrance indigenous people are accustomed to. The colonial entry into native territories coincides with the suppression of the individual ways of remembrance of the people. The indigenous subject's individual and collective ways of remembrance collide with colonial ways of remembrance. Both attempt to consolidate and perpetuate their subject-positions.

The colonial subject, however, subsumes the indigenous mind and its ways of remembrance into the colonial register of collective memory. The collective memory is employed to secure ideological and political ends. Colonization is an ideological and political project; colonial narratives of memory deliberately blur the line between individual and collective memory. Therefore, the colonial subject remains involved in the project of controlling and manipulating indigenous ways of remembrance. Consequently, the colonial subject permutes Halbwachs's script on the interaction between individual and collective memory. To stretch and maximize its discourse of power, the colonial subject uses memory as a tool, thus unleashing hegemony and oppression. In Gender and Memory Selma Leydesdorff $(2005,8)$ explain the dialectic between memory and power: "the intertwining of power and memory is very subtle, and it reflects ... the particular area of power $\ldots$ and the various levels of public discourses. Memories supportive of subordinate groups can also show striking resilience, and they can be transmitted ... from the interstices of society, from the boundaries between the public and private." This amplifies the parameters 
Halbwachs draws on memory: the connection between individual (personal) and collective (public) memory persists for its respective ends and objectives, and as individuals and groups straddle upon each other's memory, they create a variegated tapestry of the dialectic of power. The indigenous people are the subordinate group whose laws of remembrance capitulate to colonial hegemonies. But on the other hand, colonial agency also communicates its laws of remembrance to native individuals, however adapts a certain subject-position towards them, which is both supportive and alienating. The fissures and fault lines between indigenous and colonial ways of remembrance become unpacked. Analogously, colonial and postcolonial discourses employ memory as a tool to delve into the complexity of remembrance. As in sociological discourse, in colonial and postcolonial discourse, too, memory pushes the boundaries between individual and collective remembrance.

I am particularly interested in the concept of the intertwining of memory discourse with power discourse; individuals braid discourse of power which eventually shapes groups, societies, nations, and empires into cumulative sites of power. Likewise, in colonial and postcolonial literary narratives, power discourses are transmitted through a variety of personae that replicate, contest, and recuperate laws of remembrance. The sociological "interstices" are potential sites of mediation between a subject's individual and collective remembrance; these are sites of discursive power. It also suggests that no remembrance is seamless. Every memory is bordered with or bordered upon one or many types of memories; every individual in his social context creates a willing suspension of disbelief that his power of remembrance is wholesome and intractable. An individual's or group's conviction that it possess an infallible memory signifies the subject's desire for power. Andreas Huyssen $(1995,3)$ elaborates the Western (colonial) episteme of memory, a tool of power, in the metaphor of twilight: "twilight is that moment of day that foreshadows the night of forgetting, but that seems to slow time itself, an in-between state in which the last light of the day may still play out its ultimate marvels. It's memory's privileged time."The metaphor of twilight explains the complexity of interaction between individual and collective memory. Huyssen asserts that no memory is complete and any such claim mirrors the subject's inadequacy to accept the lacunae in one's faculty of remembrance. It is a fact which the colonial mind too often undermines in order to perpetuate its power over an arguably weaker subject. Ironically, 
the chances of forgetting and remembering one's individual and collective memory are equal. Therefore, in a Halbwachsian sense, the connection between individual and collective memory is both a point of strength and vulnerability - a twilight zone of uncertainties and ambiguities, of consolidation and dispersal. Individual memory becomes exposed to the collective sociological order, and, in turn, the collective memory becomes an insufficient template of individual memory. The intermediate-twilight-position which memory occupies in human consciousness alludes to intersections which Halbwachs identifies between individual and collective memory. The colonizer's collective memory, embedded with political discourses of power, is a "privileged" time. By implication, colonial texts are privileged productions of the colonial project; they employ narrative strategies to deconstruct indigenous ways of remembrance. "Privileged time" is a trope of colonial hegemony. The time which colonial agency spends establishing its paradigms of power structures, which Halbwachs terms as "laws," is a privileged moment in colonial imaginary. The colonial agency accords a privileged status to its ways of memory against which indigenous the individual, society, and nation revolt in order to preserve their ways of remembrance. It illustrates that colonial and native/postcolonial discourses of memory are embedded with power. Both discourses become engaged in preserving their memories; one of its glories, the other is of its resistance.

Halbwachs $(1992,38)$ says "that [memories] are preserved in my brain or in some nook of my mind to which I alone have access: for they are recalled by me externally and the groups of which I am a part at any time give me the means to reconstruct." The preservation of memory is a sociologically codified practice. Literature, too, deals with preservation and reproduction of individual and collective memory. This drives home the significance of exploring: a) elisions between literary memory and collective memory, and b) connections between postcolonial and cultural memory.

\section{LITERARY, CULTURAL, AND POSTCOLONIAL MEMORY: HALBWACHSIAN TRAJECTORIES}

Colonial and postcolonial literatures preserve, reconstruct, and reproduce memory of their histories. The collation Halbwachs envisages between individual or internal memory and collective 
or external memory elongates preserving collective memory from disintegrating into too many autonomous, discursive, and obscure categories. But scholars agree that "collective memory" is not a blanket or umbrella term, and, therefore, it cannot escape from the diversity of categorization. Within the purview of postcolonial narratives there is one adjustment which is certainly productive: sociologically inscribed collective memory and literary memory come together, because like collective memory, literary memory is also employed for ideological or political ends. Lars Eskestein (2006, ix) states that literature is also a "complex [...] mnemonic machine." The colonial and postcolonial literatures are the embattled site of political and ideological mnemonics. Catherine Jones $(2003,29)$ states that "literary memory ... refers both to what is retained or stored in the mind and what is recombined and produced by it." In literary narratives, what the mind of a character retains is his individual memory, and what his mind reproduces after a specific period of retention and in the wake of some specified event (context) is the Halbwachsian version of collective memory in literary terms. Halbwachs also sees individual memory instrumental in compounding collective memory. Hence, Renate Lachmann (1997, xiii) says that "literature is not a representation of . . memory; rather it enacts the operations of memory." Literary narratives, both colonial and postcolonial, are grounded in cultural, historical, and political conflicts, and they thus employ and treat the Halbwachsian notion of collective memory in the sense of cultural memory.

After all, collective memory is the memory of a socially and culturally codified group or nation. Stephanie Wössner $(2010,9)$ says that "cultural memory [ ...] does not recall everything concerning the past but of certain crucial events." Colonization is a crucial event, and in colonial and postcolonial literary narratives, the event of colonial occupation is reconstructed; whatever is reconstructed, however, is not an identical copy of actual experience. A colonial literary text, then, reprocesses collective memory of Empire, but this reproduction is partly authentic and partly inventive. The inventive portion is fictional (subjective). It is what Halbwachs defines as individual memory, because the individual subject confides individual memory; thus, the necessity of communicating one's individual memory is always secondary. It is on this account that the indigenous and colonial ways of remembrance become interlocked when they come to terms with their respective notions of cultural memory. 
Moreover, the Halbwachsian discourse on memory tangentially evokes the concerns which the postcolonial literary memory affords. Peter Consenstein $(2002,13)$ states that "literary memory is a function of conscious memory." The collective memory is also a consciousness of a group and society. The collective memory is designed to operate as a force of society, and colonial occupation is a manifestation of force or power. It means that collective memory, given the contexts in which it operates, is designed to impose its ways of remembrance, its socioethical creeds. Iain S. MacLean $(1988,31)$ is of the view that "the ethics of postcolonial memory are designed to respond the challenges of remembering." But what the Empire or the colonial subject remembers and reproduces inevitably clashes with the remembrance of the colonized and the decolonized. Sara de Mul $(2011,10)$ thus rightly states that "the colonial experience does not seem to pass instead instigates a compulsion to return." So in literary narratives, memory hinges on anecdotes of nostalgia and reminiscence. In postcolonial narratives the desire to recall the past is acutely rehearsed. The postcolonial theorist Kwamwe Anthony Appiah (1995, 119) argues cogently, therefore, when he says that "the post- in postcolonial ... is the post- of the space-clearing." In Halbwachsian discourse, collective memory also configures in spatial terms. The topography of collective memory comprises socio-cultural landscapes. Collective memory inhabits time and place, and in postcolonial narratives, memory also configures as a spatio-temporal trope. Colonial and postcolonial mappings of memory are inscribed with geographic and cartographic markers. Therefore, in both Halbwachsian and postcolonial senses, "memory forms the generative principle of writing; it functions as the place where the conversation with the past takes place" (Nünning et al. 2006, 249). The postcolonial theorist Tabish Khair says that "when one is confronted with a term with 'post' appended to it as in postcolonialism-one is forced to face up the fact of memory" (Khair.2006, 259). The postcolonial subject relives, recalls, and faces the legacy of memory, but in the process also encounters invasions on its memory, thereby employing counteractive strategies to preserve the ways of remembrance.

In Conrad's Heart of Darkness colonial memory registers and preserves the natives' ways of remembrance. The narrative recalls and reconstructs the memory of a time when Congo was an imperial colony. Marlow, the primary narrator, is a wandering seaman who comes across devastating episodes of colonial greed and plunder. His 
colleague Kurtz, whose health is failing, is the Company's agent, but between them, they make a dream team of explorers who pioneer the project of tracing anthropological and vestigial origins of primitive races and their pattern of memory. Marlow comes back to Europe a changed man, and his personal and collective memory of the native African life undergoes a unique transformation so much that he terminates his recollection of journey on a lie. He calls his journey the culminating point of his life, which ironically ends in distortion of facts. He also calls his journey a combination of dreams and nightmares, and its "memory of gratified and monstrous passions" (Conrad [1906] $1992,80)$ continues to haunt him even after his return to Europe. The "memory of that time" which Marlow spent in Congo becomes problematic, because if it is the collective memory of the Empire, then the affinity he enjoys with natives on a personal level is a pretension. He thus experiences intermittent attacks of amnesia, and develops an obsession with lies which expose his faculty of remembrance. He calls people "shadows" and "shapes" (ibid., 18). His perception of time undergoes a serious crisis. Marlow's crisis is indicative of the fact that the native African subject resists Marlow's (the colonial subject) invasion on its ways of remembrance.

\section{INDIGENOUS AND COLONIAL WAYS OF REMEMBRANCE: COUNTERACTIVE STRATEGIES IN HEART OF DARKNESS}

Heart of Darkness is a novel of recollection, reminiscence, and retrieval. Conrad constructs a nuanced narrative scheme. There is a primary narrator, a kind of supplemental voice, edged upon a neutral narrator; and then there is the protagonist, Marlow, a sort of omniscient voice, whose sense of time and space remains confounded. Marlow is not a traditional storyteller, and Heart of Darkness is not a linear text. Conrad (ibid., 19) deploys this narrative technique to deconstruct the "muddle" which the European colonialists both create and encounter. Marlow's journey is divided into three phases: Inner Station, Outer Station, and Central Station. There is virtually no plot in the novel, and the timeline disrupts frequently and vaguely. The novel captures incidents of colonial insertions, and Marlow's ultimate encounter with the Company's agent Kurtz. The novel ends on Marlow's return to Europe after the Company's agent Kurtz dies. The life which Marlow 
encounters in Africa is "unspeakable" and "incomprehensible" (ibid., 12). Words such as "haze," "fog," and "mist" resonate in the text of Heart of Darkness, indicative of a state of muddle in which the colonial ways of remembrance are caught. The natives in Heart of Darkness have no feelings of nostalgia and exile because they have no "excuse" of being there. But they cause this state of muddle for the colonials who operate in an alien context. The narrative thus enacts counteractive strategies: the indigenous people preserve their ways of remembrance, while the colonial ways of remembrance plunge into a state of muddle. The colonial memory is rhetorically caught in structures of erasure and oblivion. Moreover, Marlow's interaction with the African natives is a fricative experience, and on many occasions the colonial and indigenous ways of remembrance collide. Consequently, the natives' counteractive strategies manifest in two realms: natural and human.

\section{COUNTERACTIVE STRATEGIES: NATURAL REALM}

The natural landscape of Africa has a certain mystique for the outsiders. As Marlow catches sight of the African coast, he is psychologically consumed by the primitive wilderness of the inland. He feels as if some colossal but invisible force stops him from making ingression into African landscape: "the coast seemed to keep me away from the truth of things" (ibid., 14). To the outsiders, the natural wilderness is unwelcoming. Marlow intrudes on primitive memory of African wilderness. The landscape he encounters invokes opposition, blocking the colonial subject from inseminating its memory into the virgin vegetative world. The complex analogy of rapist and virgin signifies the epistemological intoxicants the colonial subject injects into the African memory of its past. In the images of hostile topography, Conrad conveys the effectiveness and alertness of the natives' memory; it operates against foreign occupation in defence of the African landscape. The "great wall of vegetation" is, therefore, a barrier which Marlow finds impossible to surmount. The native landscape threatens the colonizer's faculty of recollection. Desperate to elucidate an alien landscape, Marlow ends up saying, "I am trying to tell you a dream" (ibid., 31). Halbwachs $(1992,43)$ says that "dream and aphasia ... are states where the field of memory is most characteristically narrowed." Moreover, "an aphasic forgets that he is a member of society" (ibid.) Although Marlow does not sever his communication with his fellow 
"pilgrims," his faith in social discourse is considerably shaken because he is removed from his European cultural context. He hesitates in elaborating the sublime and "mysterious life" (Conrad [1906] 1992, 74) of the wildernesses. This hesitation is symptomatic of the fact that the indigenous laws of remembrance operate unobtrusively, whereas those of the colonizer become narrower and are arrested in confusion.

Marlow's faculty of remembrance, therefore, becomes compromised on two grounds: the limitation of his discourse with African natives, and the imposing silence of the "soundless life" (ibid., 34) of the jungle. Consequently, Marlow engages with an environment where the line between one's personal memory and collective memory often blurs. This blurring is caused by a subversively awesome and counteractively impenetrable primeval landscape. Beyond the native wall of "mystery, its greatness, the amazing reality of its concealed life" (ibid., 29), there is a primeval reservoir of human memory, untarnished and uninfected by a politically codified collective memory of greed and lust, of which Marlow is also a bearer. The primeval memory manifests through natives' rituals which echo around Marlow admonishing him to go back to his "sepulchral city," Europe (ibid., 65). The primeval ways of remembering counteract civilizational ways of remembering.

\section{COUNTERACTIVE STRATEGIES: HUMAN REALM}

Now I examine how the natives counteract the colonial ways of remembrance in the human realm. Conrad does not address the Company's agents by proper names; he calls them "white pilgrims." It is more of an ironic moniker. Their identity diminishes and so does their grasp on life and memory. The appellation of "white pilgrims" is illustrative of the fact that the imperial infrastructure recruits the European men for a collective campaign (colonization). But in the process, their memory "plays an extraordinary trick," as what Samuel Beckett says in Waiting for Godot. On the other hand, Conrad (ibid., 41) addresses the natives as "shapes," "phantoms"-airy, reducible, ephemeral, as if nonexistent. Notwithstanding, Marlow derives consolation from the "black shapes" as "they were a great comfort to look at" (ibid., 14). The aesthetic interaction between memory and the gaze comes into play. However, it is the native subject which causes this aesthetic stimulation. Marlow's gaze becomes arrested; thus, by implication, the colonial ways of remembrance become ceased-a 
counteractive strategy. The colonial gaze is prevented from invading on the natives' ways of remembrance.

Marlow's meeting with Kurtz's African mistress, who is "the wild and gorgeous apparition of the woman" (ibid., 74), also manifests confrontation between native and colonial ways of remembrance. There is no name for Kurtz' black mistress while his fiancée in Europe is named as "the Intended." By comparison, the African mistress was not intended to be his partner, but goes along with his crew as booty to his plundering raids and expeditions. Marlow describes her as "savage and superb," "magnificent," "stately," "ominous," "tragic," "fierce," and "dumb" (ibid.). The set of paradoxical images suggests that the colonial ways of remembering and recollecting lives of the African people are trapped in their own contradictory gazing. As for Kurtz's mistress, she is in harmony with her surroundings and does her ritual of protestation when the Company's people arrive at the Inner Station to take away the dying Kurtz. As compared to Marlow's acquiescent gaze, Kurtz's mistress has a look with an "unswerving steadiness of . . . glance" (ibid.). With her furious gaze she charms colonial spectators around her into an incantatory state of submission. Marlow reports that she vengefully "gleamed at us" (ibid.), and then disappeared into the forest leaving them dumb and shocked. Postcolonial theorist Gloria Anzuladia $(1987,42)$ says that "a glance can freeze us into place." The glance is a metonymy for individual memory. A part of Marlow's memory is reterritorialized by the natives. The mistress's rage and fury is a sign of native's contestory gaze; the indigenous gaze distracts the colonial subject and, consequently, the colonial ways of remembering Africa dissipates into fragments of memory. Marlow's narrative is fragmentary and sketchy. The uncanny African mistress engenders an incantatory blackout; Marlow's faculty of remembrance becomes stunted. The colonials' ways of recollecting Africa is hit by anxieties; their description of Africa is hazy and elliptical. In Kurtz's African mistress's compellingly interactive and counteractive gaze, Conrad tells the differences between the indigenous and the colonial ways of remembrance.

At the Outer Station Marlow meets the Company's Accountant, who is obsessed with the idea of making correct entries in his register. He makes entries and deliriously mumbles his creed that if one has to make a correct entry, one has to hate the savages. The absurd analogy the Accountant draws points to the embedded discourses of hegemony in colonial ways of remembrance. Despite having this extraordinary 
arrangement, the Accountant suffers from amnesia, and, at times, his mind becomes void. Nevertheless remains neurotically committed to his accountancy while the wilderness and silence obliterate his ways of remembrance. Consequently, in an environment infested with the white man's doubts, absurdities, and scepticisms, Marlow's collective memory becomes occluded. The natives wear "grotesque mosques" (Conrad [1906] 1992, 14), and perform "unspeakable rites" (ibid., 137). The natives' life, as the text informs, is overlaid with cannibalistic cultures, notwithstanding the authentic mode of reliving collective primeval memory of their past. Entrenched in their environment, the natives have no fears of memory-erasure; the Accountant, however, is unable to face the petrifying effects of amnesia. In comparison to a scripted colonial remembrance (Accountant's register), the natives'oral remembrance is original and abiding. Conrad envisages the native's capacity for oral remembrance as a mode of counteraction.

But it is Marlow's individual memory of the company's agent Kurtz - the symbol of imperial power-which remains intact; and since individual memory cannot be communicated, the authorial voice stitches literary memory with individual and collective memory in literary narratives. Therefore, all "Europe contributed to the making of Kurtz" (ibid., 136); he is a product of collective colonial remembrance. The solipsistic "all" denotes that in Kurtz's character, Conrad envisages memory as a multifarious and embedded discourse. He supposedly knows "all." However, Marlow discovers a bond with the natives, and also identifies a "distant kingship" (ibid., 140) with Kurtz. Marlow claims to produce an unprejudiced script on the African reality, but his relationship with Kurtz causes the unpacking of the colonial myth of perfect ways of remembrance. Marlow is overawed by Kurtz's intellectual capacities. He eulogizes him to a divine status: one that explores, documents, and recollects the relics of the savages' memory and their primitive lives. Marlow's rather gloomy conviction that for the rest of his life he is destined "to dream the nightmare out to the end" (ibid., 194) thus illustrates the fact that, although he admires Kurtz, in the natives' memory Kurtz remains a plunderer, which signifies that the natives counteract the colonial ways of remembrance. They defy adapting the colonial ways of remembrance.

Halbwachs $(1992,51)$ says that "mind reconstructs memories under the presence of society." The interaction between one's mind and one's immediate society determines qualitative productivity of human recollection. In Marlow's narration, the line between 
illusion and reality recurrently blurs: "I remember it, but I can't explain” (Conrad [1906] 1992, 55). Marlow' faculty of recollection is seriously impaired. He stumbles into a no man's land plagued by phantasmagoria, hallucinations, nightmares, surreal fantasies, and reveries. The natives' ways of remembrance are like their "glistening" (ibid., 14) black eyes and bodies whereas the colonial memory is wrapped in their cultivated fastidiousness, manners, and sartorial elegance. The colonizer's interference into the "ageless" memory of primitive Africa causes a transient state of "native insomnia" that threatens to degenerate into a permanent forgetfulness. In colonial discourse forgetfulness is a hegemonic tool. Lachmann (1997, xii) is of the view that "it is the catastrophe of forgetting that has to be counteracted, and memory ensures the resurrection of what has irrevocably perished, which however, can be only resuscitated through the presence of what it is not." Marlow's lie at the end of the novel to Kurtz's mistress, that Kurtz loved him, is the colonizer's volitional amnesia; a cultivated forgetfulness is a sign of the capitulation of the colonial ways of remembrance. But telling a lie is an ethical defection; memorization is meant to separate truths from lies. Marlow, educated in Europe and proud of his heritage, encounters his own failings. The natives do not lie. Marlow says that he hates lies, and yet his memory of Africa is riddled with lies. The native's truth is uncontaminated like their natural landscape, but incommunicable like its primitive silence. The natives yell and cry and celebrate in a language which the civilized memory of the colonial subject cannot comprehend and contain. Marlow's language and narration is elliptical and punctuated with silence. He experiences frequent memory lapses; he faints, recovers, and collapses. When he goes back to Europe, he is unable to concentrate and, for many days, wanders aimlessly in streets. On the other hand, the natives do not need to resurrect their memory. Their memory is uninterruptible. The colonial subject needs to differentiate the individual remembrance from the collective. The native's mind is not divorced from their society. They counteract the colonial ways of remembrance on account of their visceral bond with primitive ethos.

Clearly, Marlow and Kurtz cannot penetrate into the mystery of the native past beyond a certain point. However, the success story of their ways of recollecting African history and past is dispatched to Europe. The accounts of colonial success in territories are invested with distortions; the European mind, back home, must be inscribed with a philanthropic imprint. Arguably, Western or colonial ways 
of remembrance are scientific and accurate. Kurtz prepares a report which will serve as a future guidance for the Company; Marlow hides this report and does not share it with the Company's hierarchy. The European audience must receive Marlow's tale as a work of colonial "trustworthiness." Kurtz, despite enjoying a godly position, encounters limitations while deciphering primitive roots of the native memory. He uses violence to cover up his incapacities. The postscript of Kurtz's report runs as "exterminate all the brutes" (Conrad [1906] 1992, 32). He recommends erasure of the natives' memory-spaces. But in this process, his memory of civilization also becomes atrophied. Kurtz's deathbed confession—“the horror! the horror!” (ibid., 90)—signifies his inability to decode the natives' way of remembrance in totality. He encounters a stiff resistance from the indigenous people. The native individuals have not sworn to any ideological commitment like the imperial agents, yet they are a cohesive unit. The Company's agents bicker and slander. The natives have an unspoken camaraderie among themselves. Like the colonials, the natives are not caught in structures of pretension and veneer. The natives' memory is not codified by collective agenda, be it political, national, or even personal. The interaction between the colonial and the indigenous subject produces new structures of thoughts: emancipatory, assimilative, and counterhegemonic. Indigenous memory is, therefore, invariably inscribed with ideologies, such as nationalism, in the postcolonial phase. Nationalism is an embattled site on which the colonial and indigenous ways of remembrance produce new discourses on memory. The subject's memory, as it moves from colonial to postcolonial spatiality, encounters transition.

\section{MEMORY AND WAYS OF REMEMBRANCE: TRANSITION FROM INDIVIDUAL TO NATION}

In Heart of Darkness, individual and groups co-opt counteractive strategies. Individual characters represent individual memories of African life, because the Congo which Conrad depicts in Heart of Darkness was a country of scattered tribes and groups. But as we move into postcolonial era, the postcolonial subject reinvents the nation through his indigenously rooted memory. Olick and Robbins (1998, 636) are of the view that "the dominance of national memory over other memories ... not only excludes other contestants for control 
over the national identity but maintains the primacy of national over other kinds of identity for primary allegiance." However, colonized societies took some time before they channeled their remembrance of their past, culture, and identity through nationally codified discourses. The concept of nation as a cohesive unit and a collective family is reinvented, and is reiterated in postcolonial narratives. Although, the colonial subject departs from the territories, but among the natives it creates a social class, the comprador, whose ways of remembrance, on account of their greater proximity with colonial cultural, become hybrid. The comprador looks after the colonizer's interests. After the emergence of this class the colonial and postcolonial memories interact more frequently on bicultural or multicultural sites. The comprador class becomes a bridge between the native and the colonial subject; ways of remembrance become intertwined. In Heart of Darkness, Marlow refers to one of the natives as "the improved specimen" (Conrad [1906] 1992, 43) of the Empire; he is a "fine chap" (ibid.) and a protégé of the colonials. In the colonial register of memory, he is enlisted as a friend. But as he adapts the colonial way of life, he becomes the "eddying ... dog in a parody of breeches and feather hat" (ibid.). His originality is compromised through mimicry. Actually, it is the "comprador memory" which bisects the colonial and the native ways of remembrance. With the emergence of the comprador class, nationalism began reinventing a myth of indigenous memory; colonial memory was diagnosed as an intoxicant from which the national consciousness was to be cleansed. The colonized societies, driven by a national rhetoric, circulate the myth of perfect and pure structures of remembrance. That is to say, postcolonial discourse projects the binary of inside and outside. Hence, nationalism glorifies indigenous histories and the past. German archaeologist Jan Assmann (2006, 87) states that "past is the decisive resource for the consciousness of nationalidentity." Therefore, in postcolonial literature past is an archaeological source of memory. As a rule, the postcolonial texts unremittingly engage in a process of recollection of the nation's past.

German literary critic Nünning (et al. 2006, 3) is of the view that the "fictional texts have engaged in a discussion of the implications, the problems, and the purposes of remembering." The postcolonial novels construct paradigms of remembering the nation in tropes of identity. Desai's novel Clear Light of Day is a postcolonial novel in which memory configures as a double mode of resurrection and counteraction. In Clear of Light Day, Desai presents a family whose 
ways of remembering India, in the aftermaths of colonial departure, collide with the colonial ways of remembering India. In the novel, there are no characters representing the colonial memory of Empire, but there are references to colonial literature, anti-colonial national struggle, political players-Gandhi and Nehru-and the events such as the colonial departure and the partition of the Indian subcontinent in 1947; these are tropes of colonial presence. The encounters between the colonial and Indian ways of remembrance become manifested through these events. Nünning (et al. 2006, 5) is of the opinion that a postcolonial text employs "subversive counter memories challenging the version of the past." In Clear Light of Day, Desai reinvents memory of India's past using a double lens of indignity and hybridity. The novel exposes lacunae in the colonial version of the Indian realities. So in Clear Light of Day, memory is employed as a narrative tool to fix the colonial version of India.

The timeline of the novel is extensive and covers the events occurring between 1940 and 1970: euphoria of the Independence subsidies ensuing a period of bitter disillusionment. Desai constructs a fluid narrative of events, and characters traverse spatiotemporal and geographical divides. The novel tells the story of the Das family and the two sisters Bim and Tara who, after the death of their father and the partition of 1947, face their family's disintegration. Bim rejects marriage and stays back, while her younger sister Tara relocates to Europe with her diplomat husband Bakul. Bim looks after her mentally retarded brother and an alcoholic widowed aunt, while another brother Raja leaves after his pursuits. The novel deals with their departures and arrivals. With and after each departure and arrival, the events of the past resurface in the characters' unconscious, triggering them to recollect from their share of the memories of the past while living in the present. Dylan Trigg $(2006,20)$ argues that "beyond mental contents forgotten objects can also remerge despite our belief that they were consigned to oblivion many years ago," because the memory which is assumed erased or annihilated in a due passage of time "forces a reprisal against our will" (ibid., 31) The postcolonial logic of remembering resides in the subject's will to reinvent and rediscover the memory of its past, buried under colonial ruination. This logic shapes the characters' ways of remembrance in Clear Light of Day. The postcolonial critic Naomai Greene $(2001,237)$ argues that "as the very project of colonialism became imbued with opprobrium, memories of the colonial past — and especially, memories infused with nostalgia for 
a colonial order [are] now recognised as unjust." In Clear Light of Day, Desai's characters counteract the unjust scheme of the colonial ways of remembrance. The novel presents collusion between the colonial and indigenous ways of remembrance. I have classified counteractive strategies in three groups exemplified by Tara, Bakul, and Bim, the three main characters in Clear Light of Day: hybrid strategies, synthetic strategies, and rooted strategies.

\section{HYBRID COUNTERACTION}

Naomi Greene (ibid.) says that the postcolonial remembrance is rooted in "a world where the most troubling and 'guilty' aspects of the postcolonial past-particularly the scandal at its heart, that is, the relationship between oppressed and oppressor are consistently obscured or erased." Clear Light of Day begins on a note of wishing away the guilt which haunts the native subject as he or she relocates to the western metropolis. The guilt of abandoning ones' home and roots penetrates into one's ways of remembrance. Tara comes back to India nursing her guilt of breaching the trust her family and home invested in her. Tara's return is a gesture of reclaiming the part of her memory that she leaves behind in India, but it also signifies the need to address the dilemmas and crises which a hybrid subject is destined to face, because by virtue of his relocation and dislocation, his ways of remembering his own roots and place becomes problematic. The hybrid subject simultaneously remembers and forgets its past. In the first scene of the novel, Tara enacts her assertive will to remove the "dust and neglect"(Desai [1980] 2000,1) from its past in the aftermath of colonial departure. Tara arrives and repeats the ritual of the "rose walk" (ibid.) which she used to do in her childhood. She discovers her mother and Bim, her sister, in a different frame of time. In order to suppress her memories of cosmopolitan life, Tara immerses in the "rites of childhood" (ibid.). The "rose walk" is a symbolic gesture of retrieving the indigenous (Indian) way of remembering her past.

But her remembrance of her childhood is also linked with the painful memories of the partition, as well the consequent complacencies and disillusionments which wrought postcolonial India. Even in the wake of colonial departure, India's plight continues to compound. Tara's return to India reveals ever more acutely the mental scars inscribed on the nation's collective memory from the days of colonial presence. 
The hybrid subject consigns its memory to the extensive memory of multicultural societies. The hybrid subject also simulates alien cultures, hence his or her memory becomes deracinated. So Tara recollects India from a different subject-position. The India she finds is arrested in a posthumous colonial amnesia: "how everything goes on and on here, and never changes" (ibid., 4).Tara's return symbolically breaks the colonial spell in which India's memory of its past was stunted. Tara's memory of India enacts its own catharsis, and celebrates its release from the western retention, which was more of a detention. When she left India, she was a girl of eighteen, and in that part of her life, she surrendered her consciousness to her husband's demands. The fastidious diplomatic circles assimilate her memory of India. On her husband's behest, she adapts the cosmopolitan ethos, but at the cost of reducing her indigenous memory of India to anonymity. With her arrival to India, the non-Indian part of her memory becomes elided. Her hybrid consciousness loses its poise to a better end. Her indigenous memory of India, hitherto blocked, becomes free; the transplanted memories recede.

But because Tara represents two cultures, her individual memories become fissured and the fault lines in her ways of remembrance become revealed. She was "much travelled," "trained," and "fluent in several languages" (ibid., 11). India is a garden of her childhood memories, the "sleeping garden," in which "the coppersmiths beat on .. .tonk-tonk-tonk" (ibid., 23). The exposure to hybrid cultures produces a pedigree of crossbred memories: the native and non-native portions of Tara's memories inevitably collate, thus producing a quixotic discourse of remembrance. Psychologically, she is on a schizophrenic lane of memory. The personal insecurities residing in Tara's garbled and mixed memories become hushed in favor of multicultural diversities. She misses her "china-flat in Washington, its cleanliness, its floweriness" (ibid., 21). On the one hand, she is nostalgic about India's past, and on the other hand, spurns it; the India which she rediscovers is a wasteland of "faded and shabby gardens ... overgrown and neglected and teeming with wild, uncontrollable life" (ibid., 24). Tara's contradictory reminiscence of India signifies that her indigenous ways of remembrance are influenced by her gregarious way of life. In fact, "Tara's not quite assimilated cosmopolitanism [... . sat oddly on her" (ibid. 37). In Heart of Darkness, the black natives have "no excuse" (Conrad [1906] 1992,14) for being there. Tara also has no excuse to be ashamed of her Indian roots, but her absence from India deprives 
her of some of the crucial memoires which her sister preserves. These are the traumatic memories of the partition of 1947. The migration across the border introduced a new chapter on exilic memories in India's textbooks of history. In 1947, people migrated across the border, and their consciousness became split as they were to choose between ideologies and nationalities. Before the partition, the colonial presence was homogeneously counteracted, but after the partition, the collective indigenous remembrance was bifurcated. The memories of the horrors of the partition become inscribed on the nation's collective remembrance. Those who left India to sojourn on Western memory spaces returned with guilt of abdicating their memories of India. They pursue their individual destinies on multicultural sites where the globalized rhetoric strips their indigenous memory of homely identities. Tara unanchors her non-Indian memories, and reroots her Indian memories. Some of her memories of the past have gotten flushed away, and that is why at the end of the novel, she departs again for America. Tara's coterminous remembrance of the local and exilic memories is an extraordinary way of remembrance. Her ways of remembrance are paradoxical, a postcolonial aporia. Tara's remembrance of India is a privileged time of memory, which Huyssen calls a twilight zone of memory, a state in which the subject remembering is balanced out by forgetting. Her recollection of India is informed by her dual spatial occupancy, hence her memory enacts a counteractive strategy which is both hybrid and syncretized.

\section{SYNTHETIC COUNTERACTION}

But Tara's husband Bakul's remembrance of India filters through the official national lens: he enjoys the privilege of permuting and altering facts and memories on India. He selects the pleasant memories and eliminates the grimier. He refuses to discuss "famine or drought or caste wars or political disputes" (Desai [1980] 2000, 36) in India. Bakul's distortion of facts on India is the mimicry of Marlow's lies in Heart of Darkness. Marlow speaks lies to establish that the colonial ways of remembrance are authentic, and Bakul manipulates the truth to establish the truthfulness with which he remembers and projects India in his position of a diplomat.

In Heart of Darkness, lies configure in a redemptive light, thus testifying that memories are invented. Bakul also mirrors Conrad's 
“improved specimen," whose mind is imbued with colonial imaginary. Bakul's ways of remembering and projecting India are duplicitous. The postcolonial subject, as it straddles the colonial and postcolonial boundaries, tends to commit prejudices. Bakul's contrived and lopsided representation of India is symptomatic of a crisis. As the glorifying memory of the anticolonial struggle phases out, the new nationalists manufacture new memories. Therefore, Bakul's endeavor to invent a larger-than-life version of India is the sign of the onslaught of nostalgia. Amrijit Singh feels that "one of the staples of nostalgia is the desire for a stable referent-in the family structure" (Singh et al. 1996, 274). Bakul looks for stable references on India, which to him is like a family; he nostalgically recalls India's architectural grace, mythopoeic heritage, and ancient topography. He holds out to his Western audience the postcolonial mirror of tempered memories. The one-sided official version of history leaves a question a mark on the veracity of the collective memory of the nation from an archival point of view. Greene $(2001,237)$ explains the unique predicament of the postcolonial subject, who experiences the horrors of colonization, which, ironically, also mirror his incapacities to repair the damage inflicted on the structures of his ways of remembrance, because he is "denied entry into a shared past, imbued with the guilt and unease ... [ [and memories] become even 'guiltier' as the social and cultural climate changed." Bakul's version of India signifies the amount of guilt which the national memory carries along. The national memory could never disburden it of the traumatic hangover of the partition. In Clear Light of Day, the racial and ethnic disasters, which the nation's memory contains, are encoded in Nehru's shedding of tears on Gandhi's murder and in images of communal violence. Bim and Tara woefully recall the event of Ghandi's murder as the nation's collective memory was permanently dented. Bakul comes forward as the postcolonial man (Indian nationalist) of crisis who promises to sooth India out of her painful memories. But he is stricken with a nostalgia which, at heart, is decadent. Marcia Landy defines nostalgia as the "soul's natural way of fighting the sickness of despair" (quoted in Greene 2001, 238). The postcolonial nostalgia becomes complicated on account of its dual desire for expulsion and retention of colonial remembrances. Bakul unwittingly mimics the colonial ways of remembering and obscures the actual memory of India. Alain-Gerard Slama says that "nostalgia induces memory not to 'confront' but 'reject' history" (Quoted in Greene 2001, 237). Bakul's nostalgia for "Eternal India” (35) makes 
him reinvent what J. Varendonck terms $(1923,48)$ as "reduplicative and synthetic memory." Bakul's presentation on India thus enacts an ersatz counteractive strategy.

\section{ROOTED COUNTERACTION}

Unlike Bakul, Bim's ways of remembrance are realistic. Her memory of India and its past is not informed by the colonial remembrance. Bim is the only character in Clear Light of Day who has the ability to sift individual memory from the collective, as well as indigenous remembrance from colonial remembrance. She does not travel and confines herself to her house in Old Delhi and to her job as a history teacher in a local college. While others leave, she stays back and witnesses the horrors of partition. Like Bakul, she does not vacate her remembrance for nostalgia, which possesses the nation in the wake of the colonial departure and the partition of 1947. Bim's recollection of India is, therefore, neither hybrid like Tara nor putative like Bakul. She insinuates at Tara for her "leaving ... going away —into the worldsomething wider, freer" (Desai [1980] 2000, 4). Bim's own world is of "waiting" (ibid., 29); waiting is a self-conscious choice. She does not live a peripatetic life like her sister, so she is rooted. Her remembrance of India is rooted in the indigenous ethos. She has a feeling of moral tedium, as if India's memories of the past and present stagnate in isolation and are to be dredged up: "nothing happens ... each day is exactly like the other-plodding, uneventful and then suddenly there is a crash-mighty deeds take place-momentous eventseven if one doesn't know" (ibid., 42). The individual and collective memory of the nation sags down to an oneiric state. Thus, Bim does not consider marriage important and celebrates her spinsterhood with a subversive defiance. Marriage is a trope of subjective or individual memory. Tara and Bakul start their personal lives on hybrid locations, imbibe the colonial and migrant ethos, and thus confute and invalidate the indigenous ways of remembering India. Bim resists against cosmopolitanism and multiculturalism, which reconfigure colonial ways of remembrance. Even so, the painful experience appended to the memories of the partition causes the disinvestment of long-term mutually shared memories through relationships such as marriage. Bim's remembrance on India is, therefore, inscribed with defiant stories of historical female figures who, in their times, resisted socio- 
political hierarchies. She idealizes Rezia Sultana and Noor Jehan. Rezia was the first woman monarch of India, while Noor Jehan was an influential wife of the Mughal Emperor Jahangir. She deconstructs the personal and the political memoirs of these intrepid women for her students. On the one hand, she does not "allow" (ibid., 12) change, and on the other hand, feeds her students' minds with memories of women who are nonconformists and dissentious. Bim deconstructs the memories of India's colonial past and postcolonial present from a rational pedagogical perspective: "what did she want? [ ... ] something different-facts, history, chronology, preferably?" (ibid., 121) Tara's memory is consumed by the riotous summer of 1947, and its "fires," whereas Bim articulates her memory of the partition loud and clear: "it was the great event of our lives—of our youth" (ibid., 43). She does not "draw away from the continuities of history" (ibid.) and registers her response on the event of partition. She does not escape the fact that, after all, the partition of 1947 caused a discontinuity in the supposedly uninterruptable spatiotemporal memory of India. Bim's ways of remembering Indian are stable and rooted. Therefore, Bim's counteractive strategies are indigenous and unalloyed.

\section{CONCLUSION}

The forgoing discussion illustrates that in Conrad's Heart of Darkness and Desai's Clear Light of Day, characters as literary agents employ a variety of counteractive strategies to establish and preserve their ways of remembrance. Different discourses of memory are embedded in colonial and postcolonial literary production. Crucially, memory is a discursive filed. Memory in a Halbwachsian sense, memory in a postcolonial sense, and memory in a literary sense constitute an interfaced trajectory. The intersections among various memories reveal discourses of power. In colonial and postcolonial literary narratives, the indigenous and colonial ways of remembrance are material discourses of power, hegemony, and counteraction. Greene $(2001,237)$ is of the view that on being "drawn into the undertow of memory, we enter a world, dominated by a melancholy nostalgia that, unable to represent the true object of desire." The literary narratives draw fictional agents into a world where they concurrently destroy and resurrect their ways of remembrance. In postcolonial literary narratives the indigenous and non-native subject is embroiled in this two-fold process of destruction 
and resurrection. The notion of "entry" alludes to the colonial moment of injecting its ways of remembrance into indigenous mind; it is an epistemological incursion, and it is followed by a postcolonial countermoment of reprisal. The colonial memory enacts its project of silencing the indigenous subject. The indigenous subjects in Heart of Darkness and Clear Light of Day counteract the incursions and invasions on their memory spaces.

\section{REFERENCE}

Anzaldúa, Gloria. 1987. Borderlands/la frontera: The new mestizo. San Franciso: Aunt Lute Books.

Appiah, Kwamwe Anthony. 1995. The Postcolonial and the Postmodern. In The Postcolonial Studies Reader. Ed. Bill Ashcroft, Gareth Griffiths, Helen Tiffin. 119-24. London: Routledge.

Assman, Jan. 2006. Religion and cultural memory. Trans. Rodney Livingstone. Stanford: Stanford University Press.

Conrad, Joseph. (1906) 1992. Heart of darkness. Ed. V. G. Nair. Hyderabad: Orient Longman.

Consenstein, Peter. 2002. Literary memory, consciousness, and the group oulipo. Amsterdam: Rodopi.

De Mul, Sara. 2011. Colonial memory: Contemporary women's writing in Britain and the Netherlands. Amsterdam: Amsterdam University Press.

Desai, Anita. (1980) 2000. Clear light of day. London: Mariner Books.

Eskestein, Lars. 2006. Re-membering the black Atlantic: On the poetics and politics of literary memory. Amsterdam: Rodopi.

Greene, Naomi. 2001. Empire as myth and memory. In The historical film: History and memory in media, ed. Marcia Landy, 235-248. London: The Athlone Press.

Halbwachs, Maurice. 1992. On collective memory. Trans. and ed. Lewis A. Coser. Chicago: University of Chicago Press.

Harper, Ralph. 1966. Nostalgia: An existential exploration of longing and fulfillment in the modern age. Cleveland: The Press of Western Reserve University.

Huyssen, Andreas. 1995. Making time in a culture of amnesia. New York: Routledge.

Jones, Catherine. 2003. Literary memory: Scott's Waverly novels and psychology of narratives. New Jersay: Associated University Press.

Kenny, Michael J. 1999. A place for memory: The interface between individual and collective history. Comparative studies in society and history 41.3 (Jul.): 420-437.

Khair, Tabish. 2006. The Memory of Postcolonialism. In Literature and memory: Theoretical paradigms, genres, functions. ed. Nünning, Ansgar, Marion Gymnich, and Roy Sommer, 259-264. Tübinge: Francke.

Lachmann, Renate. 1997. Memory and Literature: Intertextuality in Russian modernism. Trans. Roy Sellars and Anthony Wall. Minneapolis: University of Minnesota Press.

Leydesdorff, Selma. 2005. Introduction to Gender and Memory, ed. Selma Leydesdroff, Luisa Passerini, and Paul Thompson, VII-XVI . New Jersey: Transction Publishers.

MacLean, lain S. 1988. Truth and recondition: Hope for the nations or only as much as possible. In Reconciliations, nations, and churches in America, ed. Iain S. MacLean, 3-40. Hampshire: Ashgate.

Müller, Jan-Werner. 2002. Introduction: The power of memory, the memory of power, and the power over memory. In Memory and power in post-war Europe, ed. Jan-Werner Müller, 1-38. Cambridge: Cambridge Univeristy Press. 
Nora, Pierre. 2010. Rethinking France: Les Lieux de mémoire, vol. 4: Histories and Memories. Trans. David P. Jorda. Chicago: University of Chicago Press.

Nünning, Ansgar. 2008. Memorial cultures and literary studies: Concepts and functions of memory as a challenge to research on witnessing. In Witness: Memory, representation, and the media in question, ed. Frederik Tygstrup and Ulrik Ekman, 97-115. Copenhagen: Meseum Tusculanum Press.

Nünning, Ansgar, Marion Gymnich, and Roy Sommer, eds. 2006. Literature and memory: Theoretical paradigms, genres, functions. Tübinge: Francke.

Olick, Jeffrey K. and Joyce Robbins. 1998. Social memory studies: From "collective memory" to the historical sociology of mnemonic practices. Annual Review of Sociology 24: 105-40.

Singh, Amritijit, Joseph T. Skerrett, Jr., and Robert E. Hogan, eds. 1996. Memory and cultural politics: New approaches to American ethnic literatures. Boston: Northeastern University Press.

Trigg, Dylan. 2006. The aesthetic of decay: Nothingness, nostalgia and absence of reason. New York: Peter Lang Publishing.

Varedndonck, J. 1923. The evolution of conscious faculties. London: George Allen and Unwin, Ltd.

Wössner, Stephanie. 2010. Collective memory and identity in Japanese American literature. Nordersted: Aflage.

RIZWAN AKHTAR is reading for his Ph.D. in postcolonial literature at the Department of Literature, Film, and Theatre Studies, University of Essex, UK. <kafkatrial123@gmail.com> 